\title{
Evaluation of free water removal from different sludge by solar energy utilization
}

\author{
Zeinab Amin ${ }^{\dagger}$, Nezih Kamil Salihoğlu \\ Department of Environmental Engineering, Faculty of Engineering, Uludag University, 16059, Bursa, Turkey
}

\begin{abstract}
The purpose of this research was to provide basic information about the conditions required for the drying of three types of sludge to reduce the problems associated with sludge disposal. By designing an integrated drying system, as a simple technology with paraffin-wax (phase change material), the drying efficiency was investigated with few possibilities for waste sludge management. According to the study by providing 1,880 $\mathrm{Wh} / \mathrm{m}^{2}, 1,671 \mathrm{Wh} / \mathrm{m}^{2}$, and 2,051 Wh/ $\mathrm{m}^{2}$ cumulative solar radiation, within $7 \mathrm{~h}$. respectively for wastewater treatment plant sludge (WWTPs.) and paint sludge, free water was released and marble sludge dried completely. The average internal temperature and moisture are the main factors for minimizing the sludge mass and volume and the heat transfer rout between the solar dryer equipment was observed. Water removal from the sludge caused the porous structure of the WWTPs. and paint sludge surface was observed using scanning electron microscopy (SEM). According to statistical analysis the goodness of the curve fit was evaluated using the R-square and root mean square error (RMSE) for all three sludge types By solar drying a large volume of sludge water was removed for easy transporting and prepared for the subsequent waste disposal operation.
\end{abstract}

Keywords: Cumulative solar radiation, Free water, Phase change material, Solar Dryer, Waste sludge management

\section{Introduction}

The amount of waste sludge production increases every year all over the world. Sludge waste management has become one of the most important issues because it is multi-phase material with high moisture content and is problematic in terms of transportation. Before using different sludges, the volume should be reduced by the dehydrating process. The cost of sludge treatment and disposal is more than $50 \%$ of the relevant budget for wastewater treatment plants [1]. According to research in the field of waste management, the sludge disposal has been studied by burial, incineration, wet oxidation [2], and recycling methods [3]. By reducing waste landfill and increasing sludge production, economical sludge disposal techniques, and energy recovery operations (biogas production) are recommended [4]. Environmental regulations for waste disposal, especially in the case of paint sludge, have made it more difficult due to its dangerous nature and organic compounds. Sludge drying is done in three ways: natural drying, mechanical and thermal drying [5]. In another study, the drying process is divided into three main types: convective, conductive, and solar drying [6]. Dried sludge caloric content increases and becomes a combustible

This is an Open Access article distributed under the terms of the Creative Commons Attribution Non-Commercial License (http://creativecommons.org/licenses/by-nc/3.0/) which permits unrestricted non-commercial use, distribution, and reproduction in any medium, provided the original work is properly cited.

Copyright (C) 2021 Korean Society of Environmental Engineers source [7]. According to the studies 32\% dewatering, 6\% drying, and $63 \%$ thickening are three recommended methods for sludge water removal [8]. In one study, dried sludge waste was used to produce ceramic materials as an environmentally friendly method [9], in another research the sludge cake after solar drying was mixed into the fertilizer pellets [10]. Recently, the use of marble sludge has become usual in the ornamental stone industry. The marble sludge waste produced by different manufactures and has been used during the recycling process in building blocks as a cost-effective method in sludge management $[11,12]$. The water in the sludge according to the binding type with vicinal solid particles is classified into two main categories of free water and bound water. In some studies, bound water is defined as freezable water and non-freezable water [13]. Also, non-freezable water is determined as fully hydrogen-bonded water as an indistinguishable phase that is only caught by a small part of sludge particles and cannot be separated mechanically [14]. The water in the sludge consists of four parts: 1. Free water, 2. Interstitial water, 3. Surface water, 4. Bound water [15-17]. Free water is not bounded to sludge particles and can be easily removed with a solar dryer. The advantages of the solar dryer are easy mounting and simple maintenance

Received February 17, 2020 Accepted June 10, 2020

${ }^{\dagger}$ Corresponding author

Email: zeinabamin13@gmail.com

Tel: +905050572263

ORCID: 0000-0002-2284-3899 
with no fuel costs [18], also the emission of $\mathrm{CO}_{2}$ gas at the solar drying plants is $15 \%$ lower than the thermal drying plants [19]. Solar dryers cause deactivation of pathogens, also, the possibility of a pathogenic reduction in covered systems is more than the open system [20]. The evaporation rate in the greenhouse dryer is higher than conventional dryers and consumes less energy [21]. The thermal drying method affects the sludge semi-solid properties. In some studies, the structural of sludge have been evaluated, including carbon, nitrogen, and specific properties, including lipids, proteins, and so on [22, 23]. Solar drying results are creating cracks and skin at the sludge surface by reducing the volume. Temperature change in the system is caused by heat and mass transfer with increasing turbulence [24]. The mass is transferred from the more concentrated area to the lower concentration and eventually to the diffusion stage. Nowadays, heterogeneous photocatalysts are used as new methods for disinfection and energy production in environmental remediation [25]. The production of $\mathrm{Dy}_{2} \mathrm{Sn}_{2} \mathrm{O}_{7}$ and $\mathrm{Dy}_{2} \mathrm{Ce}_{2} \mathrm{O}_{7}$ by the juice of Punica granatum as nanostructural photocatalyst was used for removal and destruction of organic pollutants and methylene blue contaminants [26, 27]. In another study green tea extract (GrTeEx), $\mathrm{Ln}_{2} \mathrm{Zr}_{2} \mathrm{O}_{7}$ ceramic nanostructures, and Pure $\mathrm{Ho}_{2} \mathrm{O}_{3}$ photocatalysts were used for pollutant reduction [28, 29], also Neodymium oxide and pure neodymium zirconate nanostructures were offered for the degradation of rhodamine under the UV light and eosin contaminant [30, 31].

In this study, one of the important factors in solar drying is the amount of solar radiation. According to previous research at $759.53 \mathrm{~W} / \mathrm{m}^{2}$ solar radiation intensity the thermal efficiency of the dryer was $2.59 \%$ [32]. Three different types of sludge (WWTP., paint and marble) with different percentages of solid content and intermolecular bonds were investigated in this study. After the sludge enters the drying system, with increasing temperature, the sludge turns into the lumpy and sticky form [33]. Many researches have been done on the use of phase change materials (PCM) for thermal storage and has an important effect on stabilizing the constant temperature and reducing the drying time [34]. The moisture loss is directly related to the drying time [35]. Applying PCM increases the drying time up to $3 \mathrm{~h}$ a day after sunset [36]. In this study, paraffin wax in mixed-mode dryer was used to increase the duration of solar energy storage. Mixed-mode drying system efficiency was $25 \%$ to $40 \%$ higher than simple solar drying systems [37]. Several studies have been conducted on the use of paraffin to improve solar drying efficiency [38, 39]. Paraffin-wax has been found as a suitable material for latent heat storage in the solar dryer [40]. The small scale solar drying system was constructed in Uludag University campus in Bursa/ Turkey with a slope of $30^{\circ}$. Bursa geographic coordination is $40^{\circ} \mathrm{N}$, $29^{\circ} \mathrm{E}$, and the average annual sunshine is $6.2 \mathrm{~h}$. Millions of tons of sludge are produced every year in Turkey, and solar drying system will provide opportunities for sludge disposal.

\section{Material and Methods}

\subsection{Sludge Samples}

\subsubsection{Wastewater Treatment Plant sludge (WWTPs)}

Urbanization and industrial development increase the sludge production. The raw sludge contains $60.27 \%$ carbon, $24.89 \%$ oxy- gen, 6.51\% hydrogen, 8.35\% nitrogen, and 0\% Sulphur [41]. WWTP sludge is taken from Bursa West Treatment Plant in Turkey. The used sludge sample with $20 \%$ dry matter has reached from the centrifugal mechanical dewatering process. Properties of sludge provided from the Bursa Water and Sewerage Administration (BUSKI) have been examined.

\subsubsection{Paint sludge}

Paint sludge is one of the most hazardous wastes from automotive factories and identified by the 080113 EU code number and unacceptable by landfills. Color type, method of staining and chemical content of sludge from flocculants, detackifiers biocides, anti-foaming agents, determine sludge properties, and improve management path. Incineration or combustion in cement kilns is used to dispose of paint sludge because it consists of high dissolved organic carbon. The major part of the paint sludge consists of organic polymers and solvents, also these are partially 1) pigments, 2) Binder, 3) Extender, 4) solvents. Due to the presence of uncured paint resins, the paint sludge becomes a sticky form, and transportation becomes very difficult. Water and solvent based paint spraying are done in a series of spray booths series with exhaust systems. Paint sludge contains $40 \%$ of the paint from the spray booth section [42]. The paint sludge sample provided from the Turkish Automotive Company had 56\% moisture content. Paint sludge management includes the highest environmental costs of hazardous waste management with $57.6 \%$ [43].

\subsubsection{Marble sludge}

Marble sludge appears during cutting and polishing of marble blocks and slabs. Sludges from marble processing plants are not hazardous waste and are managed by appropriate techniques. Marble slurry contains $26 \%$ water and consists of significant amounts of calcium and magnesium oxide. About $50 \%$ of marble blocks are lost during the manufacturing process. $90 \%$ of the particle size is less than $200 \mu \mathrm{m}[44]$.

\subsection{Experimental Study}

The small-scale dryer system was established with simple facilities. The greenhouse solar dryer is made of a triangular aluminum box with polycarbonate partition which is positioned on the surface of the greenhouse plate to create uniform heat flux. The system works as a mixed-mode system, which receives heat directly from the solar radiation and also absorbs the heat from the copper pipes. The recommended system consists of five glass heat pipes evacuated tubes by $2 \mathrm{~mm}$ thickness and 1.80 heights and made of Borosilicate. Copper pipes are embedded in glass tubes with a radius of $3 \mathrm{~cm}$ and a length of $2.5 \mathrm{~m}$. Each tube is also filled with $650 \mathrm{gr}$ of paraffin-wax. The glass tubes are $1 \mathrm{~m}$ above the ground with a slight slope to the greenhouse system. The solar radiation collected by dark tubes and transfers heat to copper pipes. Heat is transferred from the copper pipes to paraffin-wax. Approximately $70 \mathrm{~cm}$ of copper pipes is inserted from the bottom into the system. Heating copper pipes causes the internal air of the system to be heated and the temperature of the sludge increases accordingly as the air gets warmer. Paraffin-wax stores heat for a long time, especially in the absence of sunlight. Various types of sensors were used to measure the temperature at different points, including $\mathrm{HOBO}$ 


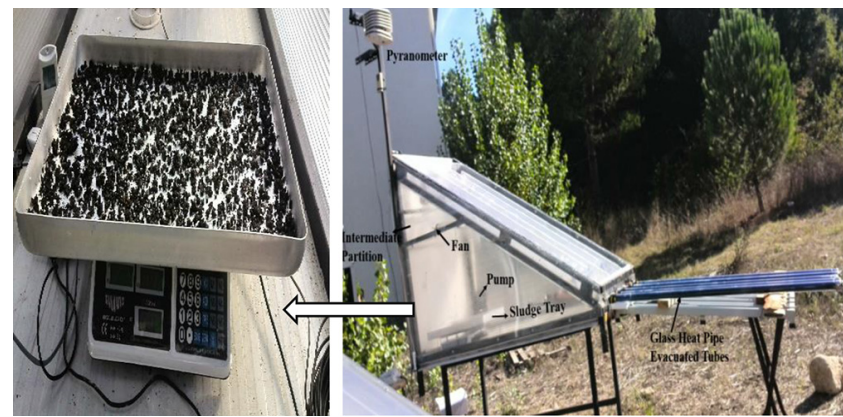

Fig. 1. Sludge solar drying system.

data logger (RX2100, onset), Digital Lazer Infrared manual sensor (WH320), FLIR E5 Infrared thermal camera, CEM (DT 185) solar data logger, Comet (S3120), which saves data for every 15 'min'. A fan with $120 \mathrm{~m}^{3} / \mathrm{h}$ air flows were used for air circulation inside the system. Also, a pump (Vaillant VCK) was used at the bottom of the system for indoor and outdoor air exchange. The polyurethane insulation covered the outer side walls of the system to reduce the heat loss to the atmosphere. Sludge samples were also spread in a rectangular aluminum tray with dimensions of $60 * 40 * 4 \mathrm{~cm}$. The collector was mounted to the south with a $30^{\circ}$ slope, also, by placing the sludge tray on a balance in the system, the water loss of sludge was calculated each hour. Fig. 1. Shows the designed solar dryer.

In Turkey 2,300,105 tons of sludge are produced annualy from treatment plants, which can be managed by solar dryers, easily. In this study, one kilogram of sludge with a thickness of $0.5 \mathrm{~cm}$ is dried on different days each time, however, in the previous seasons, $5 \mathrm{~kg}$ or more of sludge was dried even at high thicknesses. Due to the simplicity and low damaging rate, the cost of the system is low and does not require much control. The approximate investment cost of this system without sensors is $\$ 1,500$, also most of the small-scale technologies produce high-quality sludge. Thermal drying is one of the common methods for increasing sludge dry solids to above $90 \%$, but this method is very expensive because it requires a lot of energy. A greenhouse solar dryer with $70 \%$ DS performance is a cost-effective method [45]. Convective dryers have great efficiency in small areas, but, solar dryers are very effective in large areas with high sunny hours [46].

\section{Results and Discussion}

\subsection{Heat Transfer to Sludge}

The main purpose of this study was to increase the absorption of solar radiation by the dryer. One of the solutions was the use of phase change material in copper pipes with high latent heat storage potential to transfer the generated heat to the system. In this research, three copper pipes were filled with water, air, and paraffin wax, and temperature changes were measured under sunlight. After two days, the temperature of paraffin-wax was higher than the water and air. The copper pipe temperature which filled with paraffin-wax was about $2^{\circ} \mathrm{C}$ warmer than the other pipes between 07:00 a.m. - 16:00 p.m. Paraffin-wax was a good candidate PCM for specific temperature ranges. For the efficient use of solar energy as an independent source, the operation of paraffin was beneficial. Thermal distribution in the dryer system is evenly transmitted between the system materials from the outside to the inside. Before the heat reaches sludge, all surrounding materials, especially the sludge bed, must be heated, so all objects around the system are considered to be a heat source by absorbing solar radiation and play an important role in heat storage and the sludge dehydration. Heat is transferred due to temperature differences, and is absorbed by dark glass tubes and transferred to paraffin-wax and copper pipes respectively. Paraffin acts as a heat transfer medium with a melting point between $58{ }^{\circ} \mathrm{C}$ and $60{ }^{\circ} \mathrm{C}$ [47]. As shown in Fig. 2, the highest temperature changes related to copper pipes containing paraffin-wax, which raised the temperature to $50^{\circ} \mathrm{C}$ at 14:30. The heat transfer process can be seen by the difference between indoor and outdoor temperatures. The highest thermal conductivity relates to copper pipes and aluminum materials. The thermal conductivity of the copper pipes is $401 \mathrm{~W} / \mathrm{Mk}$ [48] and aluminum is $235 \mathrm{~W} / \mathrm{Mk}$ [49]. As the floor warms, the pedestals and the frame box are heated and the heat generated is transferred to the internal air. Finally, the heat is transferred to the sludge from the air by the convective method and directly from the tray by the conductive method. Since the structure of the sludge does not hold too much heat, it is important to keep the tray and the ambient temperature warm. The amount of energy transfer was equal to the amount of temperature increased in the system, and

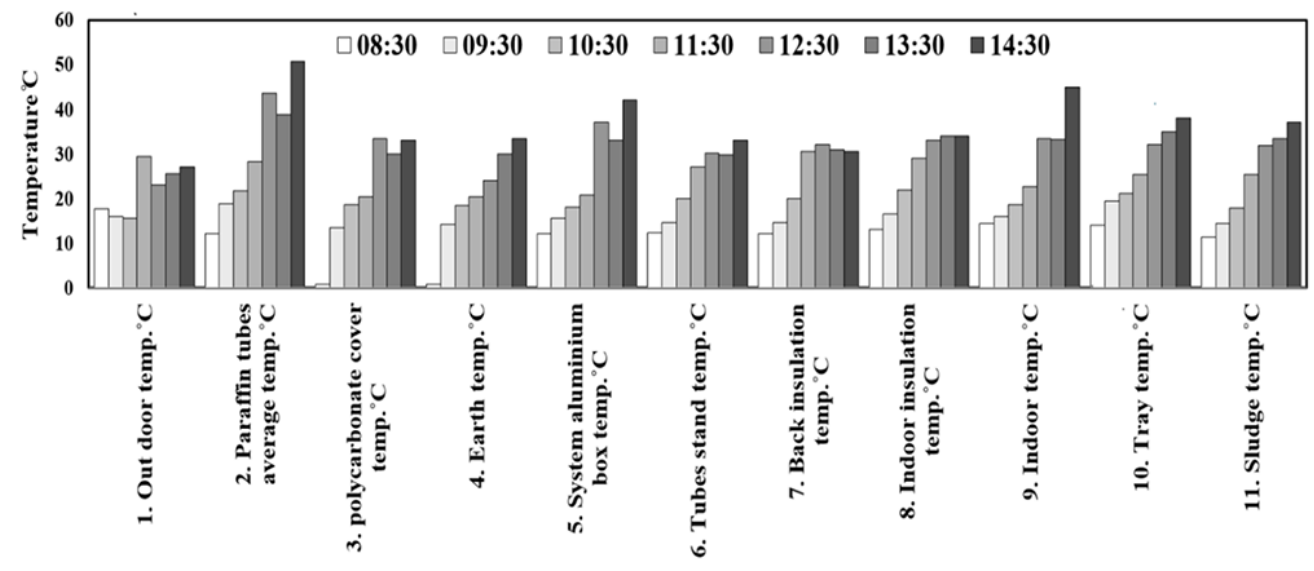

Fig. 2. Heat transfer to sludge from outside to inside the system. 
it is considered that there is heat transfer towards temperature reduction. The heat transfer process continues to reach an equilibrium temperature., The heat transfer path to sludge is shown in Fig. 2.

Free water contains the highest volume of sludge and can be removed easily [14]. Moisture change over time is recognized as the drying curve. All three sludge samples were exposed to sunlight on different days and drying performance was evaluated. As shown in Fig. 3(a), one kg of wastewater treatment plant sludge should be exposed to $1,880 \mathrm{Wh} / \mathrm{m}^{2}$ of internal cumulative solar radiation to reduce the moisture content from $80 \%$ to $17.2 \%$. During the drying process, 628 gr. from 800 gr. of sludge moisture was evaporated. The WWTPs. is usually dark black color due to the presence of activated carbon and organic matter and have a fecal odor, also the color of the sludge increases the drying speed. The formation of a thin and light color layer surrounding the sludge causes the outer part of the sludge to look drier from the inside. As the drying process proceeds, the sludge becomes sticky and the evaporation process becomes difficult. The stickiness of the sludge depends on its dryness and organic content [50]. When drying begins, internal cracks, shrinkage and skin formation appear on the surface of the sludge [33]. The evaporation rate continues at a constant speed until it reaches $50 \%$ of the total solids [51]. As shown in Fig. 3 (b), by providing $1,671 \mathrm{Wh} / \mathrm{m}^{2}$ of internal cumulative solar radiation the moisture content of one kilogram of paint sludge was reduced from $56 \%$ to $4.8 \%$ and 512 gr. of the moisture


Fig. 3. Drying efficiency in (a): Wastewater treatment plant sludge, (b): Paint sludge, (c): Marble sludge. evaporates. In addition, paint sludge contains water and a variety of organic solvents and has a bad odor due to the bacteria. Wastewater Treatment Plant sludge and paint sludge during the drying takes a lumpy shape. At 13:30 p.m. as a peak hour, the rate of evaporation in the paint sludge was higher than the WWTPs. and then in the next few hours, the rate of evaporation of the WWTPs. increased. The amount of moisture content in the WWTPs. is higher, but the free water in the paint sludge is much higher. After the free water of the paint sludge has evaporated, it enters the sticky phase and a thin and hard layer covers the external coating of the sludge. The presence of solvents and pigments in the sludge makes the evaporation process more difficult and the heat cannot enter the paint sludge. In marble sludge, as shown in Fig. 3 (c), the moisture content is reduced $100 \%$ with $2,051 \mathrm{Wh} / \mathrm{m}^{2}$ internal cumulative solar radiation. After drying, the structure of the marble sludge becomes a smooth surface with less porosity. The marble sludge dried completely within $5 \mathrm{~h}$ after receiving 1,475 Wh/m² cumulative solar radiation, due to low moisture content, and there was no change in sludge volume in the next two hours. The mean and standard error (mean \pm SE) for internal cumulative solar radiation, internal temperature, and humidity were calculated. The mean internal solar radiation for wastewater to remove free water was 226.679 $\pm 34.194 \mathrm{Wh} / \mathrm{m}^{2}$ and the maximum external solar radiation was $533 \mathrm{Wh} / \mathrm{m}^{2}$. In addition, the mean internal temperature and humidity contents were $34.31 \pm 4.59^{\circ} \mathrm{C}$ and $30.14 \pm 7.29 \%$. For paint sludge, the mean internal solar radiation was $212.347 \pm 31.761 \mathrm{Wh} / \mathrm{m}^{2}$ and the maximum external solar radiation was $488 \mathrm{Wh} / \mathrm{m}^{2}$. The mean internal temperature and humidity were $31.98 \pm 2.88^{\circ} \mathrm{C}$ and $43.51 \pm 7.65 \%$ for free water release. The marble sludge was dried with mean solar radiation of $285.007 \pm 25.480 \mathrm{Wh} / \mathrm{m}^{2}$ and maximum external radiation of $572 \mathrm{Wh} / \mathrm{m}^{2}$. Mean internal temperature and humidity were $32.3 \pm 3.32^{\circ} \mathrm{C}$ and $35.15 \pm 6.49 \%$. Approximately $1,861 \pm 190 \mathrm{Wh} / \mathrm{m}^{2}$ was found to be sufficient mean cumulative internal solar radiation within $7 \mathrm{~h}$ to remove wastewater and paint sludge free water and complete drying of marble sludge. The mean temperature of the paraffin, containing copper pipes was $45.46 \pm$ $3.91^{\circ} \mathrm{C}$ and played an important role in increasing the indoor air temperature. As shown in Fig. 3, high relative humidity reduces the apparent temperature. Dried sludge is easily transported by conveyor or truck, and has lower transportation costs. The water in the sludge causes problems for its disposal or reuse. Dried sludge reduces the production of leachate in the landfill process [52]. This research was done in the fall season and absolutely better results will be achieved in the warm seasons.

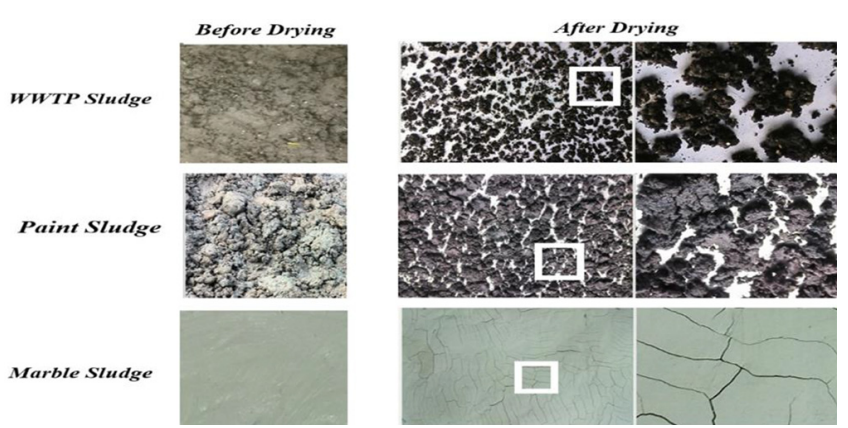

Fig. 4. Apparent deformation of three sludge samples after drying. 
Fig. 4 shows the deformation of the three sludge samples after solar drying. The structure of cracks in the inner part of the sludge depends on the drying rate. Crack formation plays an important role in the drying process, so increasing the size of cracks and porosity enhances the intensity of drying. The number and depth of cracks in WWTPs. was more than others. Due to the low percentage of moisture in marble sludge, the crack shapes are very delicate and thin.

\subsubsection{Time factor effect on drying}

As shown in Fig. 5, all three sludge samples were dried within $6 \mathrm{~h}$, by providing the necessary temperature, humidity, and solar radiation. Most of the water evaporates between 12:00-14:00 p.m. as peak hours. It is determined that time parameter is an important factor in sludge drying, in the cold season, and when solar radiation is not sufficient. If the moisture content of the system doubles and the internal temperature drops to one-third of the amount required for drying, the sludge will dry only if the time factor is tripled. As you can see in Fig. 5, when all three sludge samples are loaded into the system at the same time and exposed to the same sunlight, the free water in the paint sludge is released faster than the others. It should be noted that the paint sludge holds more heat than the other two sludges. If the concentration of solid matter increases, the water release becomes more difficult. The sludge cell wall structure limits the moisture movement quickly to the sludge surface.

\subsubsection{Evaluation of drying of three sludge types by moisture meas- urement methods}

The purpose of this experiment is to investigate the amount of free water and the adhesion of particles of any type of sludge. In fact, moisture and energy consumption was measured at short intervals, and the results of the efficiency of the solar dryer were confirmed. In this step, the Sartorius Moisture Analyzer (MA 150) is used to compare and evaluate the drying efficiency of 0.7 grams of each three sludge samples. In Fig. 6, the difference between the evaporation rate in all three types of sludge is shown. In the first seven minutes, $50 \%$ of WWTPs. (a) and $54.56 \%$ of paint sludge (b) free water evaporated by consuming $0.003 \mathrm{kWh}$ and $0.005 \mathrm{kWh}$ of energy respectively, also in the first $1 / 7 \mathrm{~min} 10 \%$ of marble sludge (c) water evaporated by consuming $0.003 \mathrm{kWh}$. After the free water is released, the sludge enters the sticky area and more time and energy is spent on releasing the remaining water. In the last evaporation process, the sludge was entered into the granular zone that is obvious in Fig. 6 as a straight line in all three samples in this region. It is known that bound water was separated from the sludge with more energy. In all three sludge samples (WWTPs., paint, and marble), all water was completely released by consuming



Fig. 5. Three different sludge samples are drying under the same solar radiation.

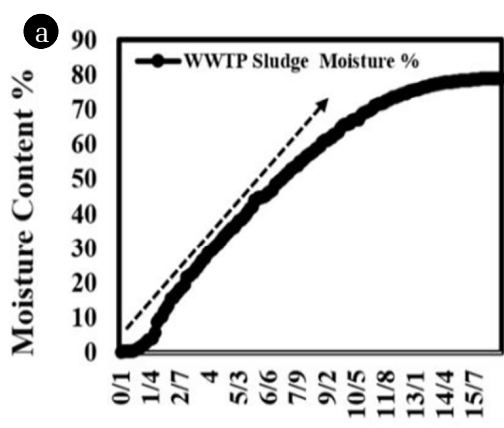

Time (min)



Time (min)

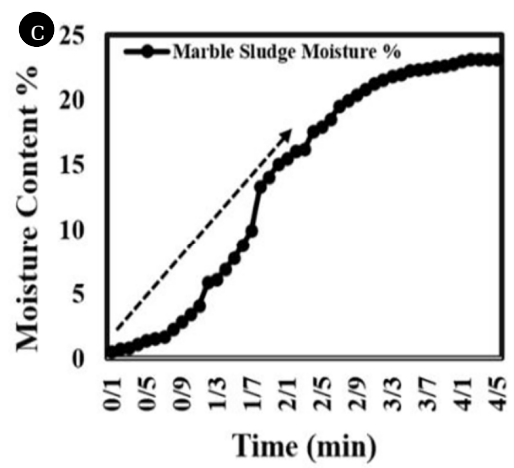

Time (min)

Fig. 6. Drying period of three sludge samples of WWTPs. (a) paintand, (b) marble, (c) sludge using a moisture analyzer. 
0.011, 0.009, and $0.005 \mathrm{kWh}$ of energy, respectively. In addition, the amount of energy consumed by the pump and fan was 0.1 $\mathrm{kWh}$ per hour in the drying system for one kg sludge in $7 \mathrm{~h}$.

Also, the rate of moisture content changes in each step was calculated by Eq. (1)[53].

$$
M C=\frac{\mathrm{w}-d}{\mathrm{w}} x 100
$$

$\mathrm{W}=$ wet weight

$\mathrm{D}=$ weight after drying

According to the researchers conducted to compare the performance of solar dryers, the moisture content of onion rings decreased from $86 \%$ to $7 \%$ in 2007 [54]. In 2010, the moisture content dropped from $82 \%$ to $18 \%$ in $8 \mathrm{~h}$ to dry $30 \mathrm{~kg}$ slices of banana [55]. Also, in another study to dry seaweed products with a solar dryer, their moisture content changed from $90 \%$ to $10 \%$ in $15 \mathrm{~h}$ in 2011 [56]. In the system designed by Eke [57] in 2014 to dry tomatoes and carrots, the moisture content of vegetables decreased from $54.55 \%$ to $21.80 \%$ and from $50.98 \%$ to $24.95 \%$, respectively. In a study on sludge drying, the moisture content of the sludge by a solar dryer fell from $82 \%$ to $5 \%$ in 2016 [58].

\section{Data Analyzing by MATLAB Program}

In this study, by using a MATLAB version R2018b software, a relationship between moisture ratio and time was indicated by using the basic formula in the polynomial model in Table 1. The $\mathrm{X}$ value represents time (h), the $\mathrm{Y}$ value represents the moisture ratio. "MATLAB" polynomial regression was used in this study to better define the situation and the values of the selectivity coefficients were estimated. According to the p1, p2, and p3 values for each sludge, $95 \%$ confidence is specified. 'SSE' means the sum of squares due to error. If the value is close to zero, the chance of an appropriate prediction increases with a random error reduction. Adjusted R-square means the residual degrees of freedom. Finally, RMSE (Root Mean Square Error) means fit standard error of the regression and determined the standard deviation of the random element. The R-square values of Wastewater treatment plant sludge and paint sludge are higher than 0.9 and low RMSE values indicating the data are fitted well. This model is the best curve fitting with the highest correlation coefficient and the lowest value of RMSE. Eq. (2) shows the calculation of the moisture ratio used in MATLAB.

$\mathrm{MR}=$ The Simplified moisture ratio

$$
M R=M_{t} / M_{0}
$$

$\mathrm{M}_{\mathrm{t}}=$ The moisture content of the sludge at each moment $\mathrm{M}_{0}=$ The initial moisture content of the sludge

The curve fitting with the drying time(h) and moisture ratio have been shown by regression analysis in Table 1 . This model was evaluated using two parameters $\mathrm{R}^{2}$ and RMSE.

\section{SEM Analysis}

The general SEM analysis method by TESCAN VEGA3 SEM device is used with 439 \& 233 magnifications for a clearer view of WWTP sludge and paint sludge morphology. Particle size plays an important role in sludge dehydration. The structure of sludge after water released in paint and wastewater treatment plant sludge was considered by scanning electron microscope (SEM) analysis. SEM analysis revealed the differences between the micro-structures of sludge particles with different moisture content. After drying, holes were observed in both sludge samples. As you can see in Fig. 7, these pores were more prominent in the paint sludge after drying and dense in different sizes. In fact, when the sludge enters the sticky phase, only internal and bond water remain between the particles, so most of these holes are caused by the release of internal water between the sludge particles [13]. After drying the marble sludge, it could not be evaluated by SEM because it reached a smooth surface, so it is not possible to observe the changes after the water is removed. Both sludge samples were placed under the same conditions in the system. Dried wastewater treatment plant sludge and paint sludge contain $11 \%$ and $7 \%$ moisture, respectively. After the moisture release pores were more prominent in the paint sludge. Pores on the sludge surface are formed due to mineral deposits [61]. In Fig. $7\left(\mathrm{a}_{1}\right)$ is shown the SEM picture of WWTPs. with $71.20 \%$

Table 1. Relationship between Moisture Ratio and Time Factors for Three Different Sludge

\begin{tabular}{lccc}
\hline & WWTP sludge & Paint sludge & Marble sludge \\
& \multicolumn{2}{c}{ Linear model Poly2 $\mathrm{f}(\mathrm{x})=\mathrm{p} 1^{*} \mathrm{x}^{\wedge} 2+\mathrm{p}{ }^{*} \mathrm{x}+\mathrm{p} 3$} \\
Coefficients & $95 \%$ & $0.004393(-0.005906,0.01469)$ \\
P1 & $-0.006929(-0.01136,-0.002493)$ & $0.0005(-0.0101,0.0111)$ & $-0.07432(-0.1493,0.0006585)$ \\
P2 & $-0.04683(-0.07912,-0.01455)$ & $-0.08869(-0.1659,-0.01149)$ & $0.2863(0.1739,0.3986)$ \\
P3 & $0.8172(0.7688,0.8655)$ & $0.6102(0.4945,0.7259)$ & 0.01348 \\
SSE & 0.0025 & 0.0143 & 0.8602 \\
R-square & 0.9936 & 0.9552 & 0.8043 \\
Adjusted (R- square) & 0.9911 & 0.9373 & 0.05193 \\
RMSE & 0.02236 & 0.05347 & \\
\hline
\end{tabular}



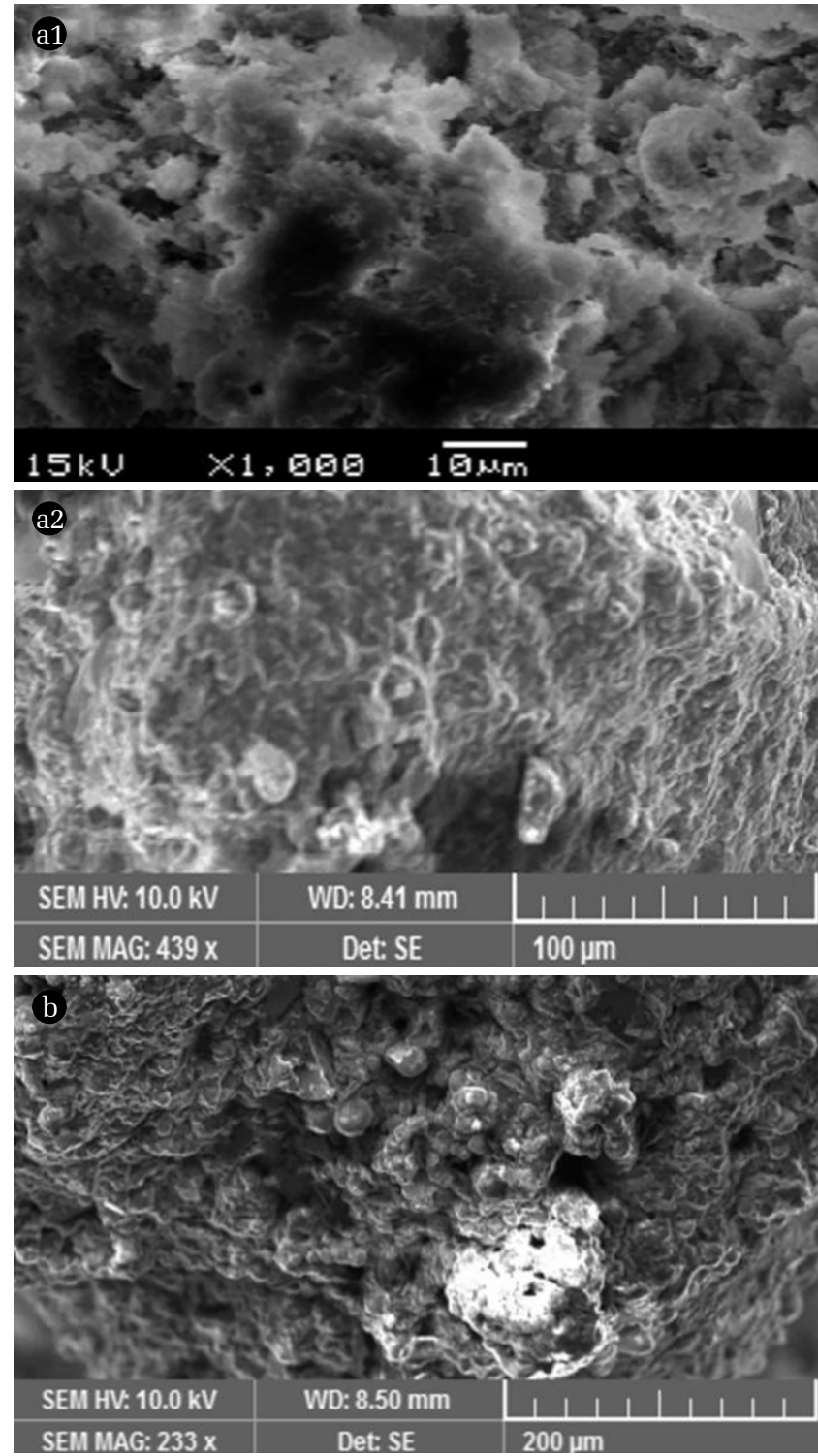

Fig. 7. SEM pictures of (a1) Wastewater treatment plant sludge with $71.20 \%$ Moisture before drying, (a2) Wastewater treatment plant sludge with $11 \%$ Moisture after drying, (b) Paint Sludge with $7 \%$ Moisture after drying.

moisture content before drying [62]. In this study, WWTP sludge and paint sludge with 100 and $200 \mu \mathrm{m}$ size are observed in Fig. $7\left(\mathrm{a}_{2}\right)$ and (b), respectively after drying.

\section{Conclusions}

In this study, the efficiency of a PCM integrated solar dryer for three different types of sludge to eliminate free water was investigated. During the drying process, there is a significant relationship between cumulative solar radiation, temperature, humidity, and time factors. After the drying process, the wastewater treatment plant and paint sludge moisture content changes from $80 \%$ to $17.2 \%$ and from $56 \%$ to $4.8 \%$, respectively, in addition to the marble sludge with $26 \%$ moisture content dried completely. The choice of equipment in the system is important for sufficient heat and mass transfer. According to MATLAB polynomial regression the correlation coefficient R-square values of Wastewater treatment plant and paint sludge are more than 0.9 and low standard error values indicate the results are fitted well. As the number of fans and tubes containing PCM increases, the efficiency of the system improves. The use of phase change materials with high heat storage capacity increases the drying time. The main point in this study is the importance of cumulative solar radiation. In fact, total sufficient solar radiation for sludge drying determined within $7 \mathrm{~h}$. The solar dryer reduces the volume and cost of transportation for proper sludge management. This type of dryer is considered to be commercialized due to its economic advantages.

\section{Author Contributions}

A.Z. (Ph.D. student) conducted all the experiments. S.NK. (Prof. Dr.) was an adviser during the entire research and also made great contributions to the system installation.

\section{References}

1. Ashley M, Arpad H, Kara LN. Hybrid life-cycle environmental and cost inventory of sewage sludge treatment and end-use scenarios: A case study from China. Environ. Sci. Technol. 2008;42(9):3163-3169.

2. Urrea JL, Collado S, Laca A, Díaz M. Wet oxidation of activated sludge: Transformations and mechanisms. J. Environ. Manage. 2014;146:251-259.

3. Cyr M, Idir R, Escadeillas G. Use of metakaolin to stabilize sewage sludge ash and municipal solid waste incineration fly ash in cement-based materials. J. Hazard. Mater. 2012;243: 193-203.

4. European Council. Directive 1999/30/EC relating to limit values for sulphur dioxide, nitrogen dioxide and oxides of nitrogen, particulate matter and lead in ambient air $\mathrm{C}$ directive. OJEU. 22 April 1999 1999;163:41-60.

5. Uggetti E, Ferrer I, Molist J, García J. Technical, economic and environmental assessment of sludge treatment wetlands. Water Res. 2011;45(2):573-582.

6. Daud LEI, Simate IN. Drying Kinetics of Sliced Pineapples in a Solar Conduction Dryer. Energy Environ. Res. 2017;7:14-26.

7. Chai LH. Statistical dynamic features of sludge drying systems. Int. J. Therm. Sci. 2007;46(8):802-811.

8. Flaga A. Sludge Drying. In: Polish-Swedish-Ukrainian Seminar Research and Application of New Technologies in Wastewater Treatment and Municipal Solid Waste Disposal; 2006; Ukraine, Sweden and Poland. P. 73-82.

9. Quina MJ, Almeida MA, Santos R, Bordado JM. Quinta-Ferreira RM. Compatibility analysis of municipal solid waste incineration residues and clay for producing lightweight aggregates. App. Clay Sci. 2014;102:71-80.

10. Collard M, Teychené B, Lemée L. Comparison of three different 
wastewater sludge and their respective drying processes: Solar, thermal and reed beds - Impact on organic matter characteristics. J. Environ. Manage. 2017;203:760-767.

11. Aukour FJ. Incorporation of marble sludge in industrial building eco-blocks or cement bricks formulation. Jordan J. Civ. Eng. 2009;3(1):58-65.

12. Al-Hamaiedh $\mathrm{H}$. Reuse of marble sludge slime in ceramic industry. Jordan J. Civ. Eng. 2010;4(3):264-271.

13. Yudianti R, Karina M, Sakamoto M, Azuma J. DSC analysis on water state of salvia hydrogels. Macromol. Res. 2009;17: 1015-1020.

14. Vesilind PA. The role of water in sludge dewatering. Water Environ. Res. 1994;66:4-11.

15. Vaxelaire J, Cézac P. Moisture distribution in activated sludges: A review. Water Res. 2004;38:2215-2230.

16. Kopp J, Dichtl N. The Influence of Free Water Content on Sewage Sludge Dewatering. Chem. Water Wastewater Treat. 2000;6:347-356.

17. Kopp J, Dichtl N. Influence of the free water content on the dewater ability of sewage sludges. Water Sci. Technol. 2001;44: 177-183.

18. Visavale GL. Principles, Classification and Selection of Solar Dryers. Solar Drying: Fundamentals, Applications and Innovations, ed. Hii CL, Ong SP, Jangam SV, Mujumdar AS. Singapore; 2012. p. 1-50.

19. Ritterbusch S, Bux M. Solar Drying of Sludge - Recent Experiences in Large Installations. In: 3rd European Conference on Sludge Management; 6- 7 September 2012; Leon, Spain. p. 8.

20. Salihoglu NK, Pinarli V, Salihoglu G. Solar drying in sludge management in Turkey. Renew. Energy. 2007;32(10):1661-1675.

21. Bux M, Baumann R, Quadt S, Pinnekamp J, Mühlbauer W. Volume reduction and biological stabilization of sludge in small sewage plants by solar drying. Dry. Technol. 2002;20:829-837.

22. Mathioudakis VL, Kapagiannidis AG, Athanasoulia E, Paltzoglou AD, Melidis P, Aivasidis A. Sewage Sludge Solar Drying: Experiences from the First Pilot-Scale Application in Greece. Dry. Technol. 2013;31(5):519-526.

23. Jardé E, Mansuy L, Faure P. Organic markers in the lipidic fraction of sewage sludges. Water Res. 2005;39:1215-1232.

24. Çerçi KN, Daş M. Modeling of heat transfer coefficient in solar greenhouse type drying systems. Sustainability 2019;11:1-16.

25. Hernández-Alonso MD, Fresno F, Suárez S, Coronado JM. Development of alternative photocatalysts to $\mathrm{TiO} 2$ : Challenges and opportunities. Energy Environ. Sci. 2009;2:1231-1257.

26. Zinatloo-Ajabshir S, Morassaei MS, Amiri O, Salavati-Niasari M. Green synthesis of dysprosium stannate nanoparticles using Ficus carica extract as photocatalyst for the degradation of organic pollutants under visible irradiation. Ceram. Int. 2020;46(5): 6095-6107.

27. Zinatloo-Ajabshir S, Salehi Z, Salavati-Niasari M. Green synthesis of Dy2Ce2O7 ceramic nanostructures using juice of Punica granatum and their efficient application as photocatalytic degradation of organic contaminants under visible light. Ceram. Int. 2018;44(4):3873-3883.

28. Zinatloo-Ajabshir S, Ghasemian N, Salavati-Niasari M. Green synthesis of Ln2Zr2O7 ( $\mathrm{Ln}=\mathrm{Nd}, \mathrm{Pr})$ ceramic nanostructures using extract of green tea via a facile route and their efficient application on propane-selective catalytic reduction of NOx process. Ceram. Int. 2020;46(1):66-73.

29. Mortazavi-Derazkola S, Zinatloo-Ajabshir S, Salavati-Niasari M. Facile hydrothermal and novel preparation of nanostructured Ho2O3 for photodegradation of eriochrome black $\mathrm{T}$ dye as water pollutant. Adv. Powder Technol. 2017;28(3):747-754.

30. Mortazavi S, Zinatloo-Ajabshir S, Salavati-Niasari M. Preparation and characterization of $\mathrm{Nd} 2 \mathrm{O} 3$ nanostructures via a new facile solvent-less route. J. Mater. Sci. Mater. Electron. 2015;26(8):5658-5667.

31. Zinatloo-Ajabshir S, Salavati-Niasari M. Facile synthesis of nanocrystalline neodymium zirconate for highly efficient photodegradation of organic dyes. J. Mol. Liq. 2017;243:219-226.

32. Seetapong N, Chulok S, Khoonphunnarai P. Thermal Efficiency of Natural Convection Solar Dryer. J. Physics: Conference Series. 2017;901(1):012044.

33. Bennamoun L, Arlabosse P, Léonard A. Review on fundamental aspect of application of drying process to wastewater sludge. Renew. Sust. Energ. Rev. 2013;28:29-43.

34. Rokade SS, Wagh MM, Bagi JS. A review of solar air dryers based on phase change materials as thermal storage. Energy-Saf. Energy-Econ. 2018;5:42-44.

35. Chen Z, Afzal MT, Salema AA. Microwave Drying of Wastewater Sewage Sludge. J. Clean Energy Technol. 2014;282-286.

36. Boda M. Papade C. Analysis of Solar Dryer using Tono Therm M-65 Phase Change Material. Atlantis Press. 2017;137:35-40.

37. Khalifa AJN, Al-Dabagh AM, Al-Mehemdi WM. An Experimental Study of Vegetable Solar Drying Systems with and without Auxiliary Heat. Renew. Energy. 2012;2012:1-8.

38. El Khadraoui A, Bouadila S, Kooli S, Farhat A, Guizani A. Thermal behavior of indirect solar dryer: nocturnal usage of solar air collector with PCM. J. Clean. Prod. 2017;148:37-48.

39. Shalaby SM, Bek MA. Experimental investigation of a novel indirect solar dryer implementing PCM as energy storage medium. Energy Convers. Manage. 2014;83:1-8.

40. Agarwal A, Sarviya R. Characterization of commercial grade paraffin wax as latent heat storage material for solar dryers. Mater. Today. 2017;4:779-789.

41. Houdková L, Boráň J, Ucekaj V, Elsäßer T, Stehlík P. Thermal processing of sewage sludge - II. Appl. Therm. Eng. 2008;28: 2083-2088.

42. Viguri J, Onandía R, Arce R, Irabien A. Alkyd paint waste characterization and distillation. Chem. Eng. Commun. 2005;192: 1490-1504.

43. Salihoglu G, Salihoglu NK. A review on paint sludge from automotive industries: Generation, characteristics and management. J. Environ. Manage. 2016;169:223-235.

44. Khaliq SU, Khan S, Alam B, Bilal F, Zeb M, Akbar F. "Marble powder's effect on permeability and mechanical properties of concrete. Int. J. Civil. Environ. Eng. 2016;10:509-514.

45. Kalderis D, Aivalioti M, Gidarakos E. Options for sustainable sewage sludge management in small wastewater treatment plants on islands: The case of crete. Desalination 2010;260(1-3): 211-217.

46. Chua KJ, Chou SK. Low-cost drying methods for developing countries. Trends Food Sci. Technol. 2003;14(12):519-528.

47. Nair AM, Naidu PVK. Analysis of Paraffin Wax as a Phase 
Change Material. Int. J. Curr. Eng. Technol. 2018;8(01):52-55. 48. Patterson JE, Miers RJ. The Thermal Conductivity of Common Tubing Materials Applied in a Solar Water Heater Collector. In: 46th ASC Annual International Conference. Wenthworth Institute of technology, ed.T. Sulbaran (Boston, MA); 2010. p.1-7.

49. Zilles JU. Thermally Conductive Additives. Fillers for Polymer Applications; 2017. p. 355-374.

50. Peeters B, Dewil R, Vernimmen L, Van den Bogaert B, Smets IY. Addition of polyaluminiumchloride (PACl) to waste activated sludge to mitigate the negative effects of its sticky phase in dewatering-drying operations. Water Res. 2013;47(11):3600-3609

51. Marklund S. Dewatering of Wastewater Sludge by Natural Air Drying. Sweden: Division of Sanitary Engineering Luleå University of Technology, Licenciate Thesis; 1997. p.3.

52. Tchobanoglous G, Burton FL, Stensel HD. Metcalf \& Eddy.4th edition; 2003. p. 1-53.

53. Reeb J, Milota M. Moisture content by the oven- dry method for industrial testing. Wdka. 1999;66-74.

54. Sarsavadia PN. Development of a solar-assisted dryer and evaluation of energy requirement for the drying of onion. Renew. Energy. 2007;32(15):2529-2547.

55. Amer BMA, Hossain MA, Gottschalk K. Design and performance evaluation of a new hybrid solar dryer for banana. Energy Convers. Manage. 2010;51(4):813-820.
56. Fudholi A, Otman M, Ruslan M, Yahya M, Zaharim M, Sopian K. Technoeconomic analysis of solar drying system for seaweed. Proc. of the 7th IASME/WSEAS. Int. Conf. on Energy, Environment, Ecosystems and Sustainable Development. 2011; Malaysia. p. 89-95.

57. Eke ABen. Investigation of low cost solar collector for drying vegetables in rural areas. Agric. Eng. Int.: CIGR J. 2014;16(1): 118-125.

58. Garanto Osvaldo. Solar Sludge Drying Technology and Dried Sludge as Renewable Energy-Closing the Loop. J. Traffic Transp. Eng. 2016;4:221-229.

59. Togrul IT, Pehlivan D. Mathematical modelling of solar drying of apricots in thin layers. J. Food Eng. 2002;55(3):209-216.

60. Önal B, Adiletta G, Crescitelli A, Di Matteo M, Russo P. Optimization of hot air drying temperature combined with pre-treatment to improve physico-chemical and nutritional quality of 'Annurca' apple. Food Bioprod. Process. 2019;115: 87-99.

61. Chen M, Zhao H, Fang H, Zhang Y. Cross-sectional information on pore structure and element distribution of sediment particles by SEM and EDS. Scanning 2017;2017:1-7.

62. Wang W, Li A, Zhang X. DSC and SEM analysis on bound water characteristics in sewage sludge. Adv. Mater. Res. 2012;347-353:2085-2089. 